\title{
A circular economy strategy for sustainable value chains: A European perspective
}

\author{
Mark Anthony Camilleri ${ }^{1}$, University of Malta, Malta and University of Edinburgh, Scotland. \\ This is a prepublication version.
}

Suggested Citation: Camilleri, M.A. (2021). A circular economy strategy for sustainable value chains: A European perspective, In S. Vertigans and S.O. Idowu (Eds.), CSR, Sustainability, Ethics \& Governance, Springer, Cham, Switzerland.

\begin{abstract}
The European Union (EU) institutions are increasingly raising awareness on the circular economy (CE) agenda. They are encouraging marketplace stakeholders to engage in sustainable production and consumption behaviours by urging them to reduce, reuse, restore, refurbish, remanufacture, and recycle resources in all stages of their value chain. Therefore, this chapter presents a costbenefit analysis of the circular economy strategy. Afterwards it features a critical review of some of the latest European regulatory guidelines, instruments and principles appertaining to the $\mathrm{CE}$ agenda. It sheds light on EU's (2020) new circular economy plan for a cleaner and more competitive Europe. Therefore, this research examines the EU's key propositions on the value chains of different products. The findings suggest that the circular economy's sustainable development model and its regenerative systems are increasingly minimising industrial waste, emissions, and energy leakages through the creation of long-lasting designs that can improve resource efficiencies. This contribution implies that successful CE practices are sustainable in the long run as they will ultimately add value to the business as well as to our natural environment. In conclusion, the researcher puts forward his recommendations to policy makers and practitioners.
\end{abstract}

Keywords: circular economy, new circular economy plan, circular economy strategy, sustainable production, sustainable consumption, European Union, sustainability, policy.

\footnotetext{
${ }^{1}$ Department of Corporate Communication, Faculty of Media and Knowledge Sciences, University of Malta, Malta. Email: Mark.A.Camilleri@um.edu.mt
} 


\section{Introduction}

The economic models of many countries are mostly built on the premise of 'take-make consume and dispose" patterns of growth (Kirchherr, Reike \& Hekkert, 2017; Camilleri, 2017a; Camilleri, 2018a; EU, 2015a; EMF, 2013). The manufacturing of products have customarily followed such a linear model that assumes that resources are abundant, available and cheap to dispose of; as every product is usually bound to reach its 'end of life' at some stage (Camilleri, 2018; Ghisellini, Cialani \& Ulgiati, 2016; EU, 2014). When products are no longer useable or required, they are often discarded as waste that is either incinerated or dumped in landfills (Kirchherr et al., 2017; Murray, Skene \& Haynes, 2017; Haas, Krausmann, Wiedenhofer \& Heinz, 2015). The circular economy proposition differentiates itself from the linear economic systems that rely on resource depleting systems that are usually characterised by high externalities, including emissions and waste generation. The circular economy is intended to reduce waste as extant resources and materials are used more efficiently (EU, 2020a, 2020b; 2014; Stahel, 2016).

The sustainable consumption of resources was recently listed as one of the priority areas of the European Green Deal as the European Union (EU) has also recognised the importance to reduce resource extraction as the reserves of some of the globe's key elements and minerals shall be depleted within the next years. Extant economic models are still relying too much on resource extraction and depletion. Currently, the national economies are very dependent on the use of natural resources as they provide crucial raw materials for business, industry as well as for individuals. The increase in global extraction of resources is driven by higher living standards and from major infrastructural investments that are happening in developing and transitioning countries (EU, 2020b). The rise of the rapid urbanisation within the emerging economies is expected to intensify the competition for certain raw materials and to destroy our natural 
environment (Stubbs \& Cocklin, 2008). Eventually, this can (it already had in some parts of the world) a devasting effect on the globe's climate. The projections are that the demand for the world's resources would more than double between 2015 and 2060 (UNEP, 2019).

The global consumption materials or products including biomass resources (like fruit and vegetables), fossil fuels (like gas, oil or coal), metals (like iron, aluminium and copper that are used in construction and electronics manufacturing) as well as non-metallic minerals (that are used for construction, notably sand, gravel and limestone) are expected to double in the next forty years (OECD, 2019a), while annual waste generation is projected to increase by $70 \%$ by 2050 (World Bank, 2018). Therefore, there is scope for governments and policy makers to incentivise practitioners to use circular economy systems, as better eco-designs, waste prevention as well as the reuse and recycling of materials can result in operational efficiencies and cost savings, whilst reducing waste and emissions (Camilleri, 2018; EEA, 2018; Kirchherr et al., 2017; Haas et al., 2015).

In this light, this chapter critically analyses costs and benefits of the circular economy. Afterwards, it sheds light on the latest strategies and policy developments within the European Union (EU) context. Them, it clarifies how the EU is promoting the circular economy approaches in different industry sectors as it encourages the sustainable production and consumption of resources and materials. In conclusion, this contribution puts forward the managerial implications to policy makers and industry practitioners. 


\section{The Circular Economy Strategy}

The term "circular economy" is increasingly being used by politicians, business practitioners and even within the civil society. Many individuals may usually associate it with recycling and/or better waste management. They may perceive that its eco-design will improve the sustainable production and consumption of the businesses and their customers. Therefore, the circular economy approaches are intended to reduce the absolute resource consumption during manufacturing (Stahel, 2016; Haas et al., 2015). At the same time, it can also minimise the generation of waste and unwanted externalities.

\subsection{The Benefits of the Circular Economy}

Hence, the governments ought to monitor and control the consumption of their land and water with a view to setting reduction targets in future (EU, 2020a, 2020b). Moreover, it is imperative that they regularly examine the carbon emissions and footprints during the production and consumption of resources in order to bridge further actions between climate change agenda and the circular economy approach. Firms are encouraged to continuously re-examine their extant operations, management systems and production processes as they need to identify value-added practices (Porter and Van der Linde 1995). Their industrial operations can be improved through redesigned processes, the elimination of some of them, the modification of certain technologies and / or inducting new technology.

Prakash (2002) suggested that the businesses could adopt management systems that create the right conditions to reduce their negative impact on the natural environment. He posited that this could take place in the following ways: (i) repair - extend the life of a product by repairing its parts; (ii) recondition - extend the life of a product by significantly overhauling it; (iii) 
remanufacture - the new product is based on old ones; (iv) reuse - design a product so that it can be used multiple times; (v) recycle - products can be reprocessed and converted into raw material to be used in another or the same product, and (vi) reduce - even though the product uses less raw material or generates less disposable waste, it could still deliver benefits that are comparable to its former version. These preventative and restorative practices are related to the circular economy.

The circular economy's closed loop systems could minimise the cost of dealing with pollution, emissions and environmental degradation (Geissdoerfer, Savaget, Bocken \& Hultink, 2017; Peeters, Vanegas, Tange, Van Houwelingen \& Duflou, 2014; Geng, Sarkis, Ulgiati \& Zhang, 2013; Geng \& Doberstein, 2008; Stubbs \& Cocklin, 2008).

\subsection{The Costs of the Circular Economy}

There may be circular economy processes that may result in negative outcomes. The idea that businesses can design longer-lasting products be considered as advantageous. However, the longevity of product designs may not be possible or feasible. The longevity of the products' life could not be sustainable and/or efficient in ecological terms. The long-lasting products that do not break down quickly may consume more useful energy and release more entropy than those that are designed towards a more natural outcome. For example, a bamboo chopstick would be more sustainable than a plastic fork as it can be recycled and removed from the biosphere. The bamboo chopstick is made of natural nutrients, whilst the plastic fork has technical nutrients. The latter cannot be re-assimilated back into the natural environment.

There are some environmentally friendly technologies, including the wind farms and solar panels that have certain metals and compounds in them that may be difficult to recycle, upcycle or downcycle. Moreover, such structures may require frequent servicing and replacements of their 
key components. Hence, the prices of these green technologies may not always reflect the real costs of their materials. These structures consist of technological components that will necessitate energy-expensive servicing and/or replacement, as nothing lasts forever in an entropic universe (Murray et al., 2017). Therefore, it may not be sustainable to delay or prolong these green products' lifecycle through regular servicing.

The transition toward a zero-waste model could prove to be a very difficult endeavour for many businesses. The new sustainable technologies could be more expensive than other technologies. The smaller businesses may not have access to adequate and sufficient financial resources to make green investments. Therefore, there may still be a low demand for the circular economy technologies, particularly if the businesses engage in short term planning. Hence, they will not perceive the business case for the long term, sustainable investment (Camilleri, 2017a; Moratis, Melissen \& Idowu, 2018). Alternatively, the businesses may not be interested in new technologies that will require them to implement certain behavioural changes (Lieder \& Rashid, 2016; Porter and Van Der Linde, 1995). Technology is one of the key factors in the development of a circular economy model. However, businesses may not always be in a position to invest in economic and efficient infrastructures.

They will surely resent any mandatory changes that are imposed on them by the regulatory institutions and policy makers. In many cases, it is very likely that they would opt to remain in their status quo, where they keep using traditional, linear economic models (Bocken, de Pauw, Bakker \& van der Grinten, 2016).

There may be other challenges that could slow down or prevent the industry practitioners' engagement in the circular economic approaches. For example, the emerging economies may decide not to follow the international principles, guidelines and recommendations to achieve the 
sustainable development goals. Their authorities and policy makers may not enforce the law on social and environmental matters in their respective jurisdictions. The developing countries' economies will probably support the corporate businesses that are providing employment to their citizens, rather than burdening them with strict regulations. Their governments may not introduce hard legislation to trigger corporations' sustainable production and consumption behaviours as this could impact on the businesses' prospects. Therefore, the businesses are not even expected to engage in corporate responsible and sustainable behaviours. As a result, they will not safeguard or protect the environment. They may not mitigate their externalities, including their emissions or unwanted waste, as such actions would require changing or upgrading the extant technologies or practices.

The social and environmentally responsible behaviours will probably usurp more corporate resources in terms of time, labour and money. Of course, the businesses that are operating is such contexts may also have to face contingent issues like weak economic incentives; access to finance; shortage of advanced, green technologies; and a lack of appropriate performance standards in their workplace environments, among other issues. The businesses may see little economic incentives to save energy, material and water. The producers can easily transfer the manufacturing costs to their customers in the form of higher sale prices.

The financial services institutions, including banks may decide not to invest in environmental-friendly technologies. Similarly, several governments may not be in a position to provide economic instruments, such as grants or tax incentives to support the businesses and clusters to implement closed loop or product service systems (Camilleri, 2018; Tukker, 2015; Wang, Wang \& Zhao, 2008; Tukker \& Tischner, 2006; Mont, 2002). Conversely, other governments from the advanced economies possess the financial resources to incentivise the 
industry practitioners' circular economic practices. For instance, most EU countries have introduced intelligent, substantive and reflexive regulations for the performance assessment of government agencies, corporations and large undertakings (Camilleri, 2015b). These jurisdictions are following the EU's (2014) directive on non-financial reporting, among others, as they disclose material information on their environmental, social and governance (Venturelli, Caputo, Leopizzi \& Pizzi, 2019; Camilleri, 2015a; 2018a).

\section{The European Union's Policies on the Circular Economy}

In the past few years, the EU has raised awareness on the importance of the circular economy agenda. It has published various action plans relating to this topic, including; "Innovation for a sustainable future - The Eco-innovation Action Plan"; "Building the Single Market for Green Products": "Facilitating better information on the environmental performance of products and organisations"; "Green Action Plan for SMEs: enabling SMEs to turn environmental challenges into business opportunities"; "Closing the loop -An EU action plan for the Circular Economy" and "Investing in a smart, innovative and sustainable Industry - A renewed EU Industrial Policy Strategy", among others (see EU, 2017). EU (2015a) anticipated that new business models, ecodesigns and industrial symbiosis can move the community towards zero-waste; reduce greenhouse emissions and environmental impacts. Its 'Resource Efficient Europe' initiative involved the coordination of cross-national action plans and policies on the formulation of sustainable growth.

The circular economy proposition was intended to bring positive environmental impacts, real cost savings, and greater profits. EU (2015a, 2015b) indicated that its envisaged improvements in waste prevention and eco-designs, the use and reuse of resources, and similar measures could 
translate to the net savings of $€ 600$ billion, or $8 \%$ of annual turnover (for European businesses); while reducing total annual greenhouse gas emissions by 2-4\%. This EU (2015a) communication anticipated that the markets for eco-industries will double between 2010 and 2020. It also posited that internationally, resource-efficiency improvements are in demand across a wide range of industrial sectors.

Moreover, in 2015, the European Fund for Strategic Investments (EFSI) has also announced a new financing avenue for future investments in infrastructure and innovation, that could be relevant for circular economy projects and closed loop systems. In December of the same year, the EU launched its Circular Economy Package, which included revised legislative proposals to "close the loop" of product lifecycles through greater recycling and re-use. Its action plan specified that the inefficient use of resources in production processes can lead to lost business opportunities and significant waste generation throughout a product's life. It suggested that product designs could make products more durable or easier to repair, upgrade or remanufacture. Operational improvements would enable recyclers to disassemble products in order to recover valuable materials and components. Therefore, the EU legislative proposals on waste management included long-term targets for the sustainable consumption and production of resources. They also encouraged the reuse and recycling of materials, including plastics, food waste; critical raw materials from electronic devices; construction and demolition resources; as well as from biomass and bio-based products, among other items. Moreover, the EU's action plan recommended further innovative investments in fields such as waste prevention and management, food waste, remanufacturing, sustainable process industry, industrial symbiosis, and in the bioeconomy to support the circular economy and global supply chains (EU, 2015a).Eventually, in March 2017, the EU Commission and the European Economic and Social Committee organised a Circular 
Economy Stakeholder Conference, where it reported on the delivery and progress of some of its Action Plan. It also established a Finance Support Platform with the European Investment Bank (EIB) and issued important guidance documents to Member States on the conversion of waste to energy.

The latest European Union (EU) Commission's (2020) Circular Economy Action Plan emphasises that it relies on the stakeholders' active engagement to achieve the European Green Deal2 for a climate-neutral, resource-efficient, circular economy. The EU has reiterated its commitment to implement the 2030 Agenda for Sustainable Development as well as its Sustainable Development Goals on resource efficiency and decoupling; on sustainable management and efficient use of natural resources; on land-degradation neutrality; and on halting biodiversity loss (EU, 2020a; 2020b). Its recent working document provides a comprehensive account about the current situation. It discusses about the opportunities and challenges, for various actors across the globe, to engage in sustainable production and consumption behaviours. Hence, it puts forward its key recommendations for the circular economy agenda.

The latest circular economy (CE) strategy is even more ambitious. EU (2020) is planning to increase the bloc's GDP by an additional $0.5 \%$, it envisages that it would create more than 700,000 jobs by 2030 (this was announced a few days before the outbreak of the 2019-2020 Coronavirus - COVID19). The EU's (2020) strategy is aimed at making the European economy even more sustainable, as the Commission is pushing the member states to exploit the untapped potential of greener product life cycles. Another European sustainability policy (that is another component o the European Green Deal) is entitled; 'Farm to Fork' (F2F), is focused on the agriculture, aquaculture and sustainable food production. Specifically, this policy covers the entire food supply chain. Its underlying objective is to reduce the usage of resources and unnecessary 
waste by promoting the sustainable production and consumption of food. It also supports consumers choose healthy and sustainable diets as they are given relevant information on the foods' nutritional value and environmental footprint. One of its key objectives is to contribute towards achieving a circular economy. It aims to reduce the environmental impact of the food processing and retail sectors by taking action on transport, storage, packaging and food waste (EU, 2019a).

The objectives of both the CE and F2F strategies are to reduce waste including food waste. The measures from the circular economy plan refer to the reduction on the use of packaging and over-packaging. At the same time, it encourages the businesses and their customers to use and reuse or recycled materials, where they can. Very often, the industry practitioners are finding ways to use fewer resources in the manufacturing and packaging processes (EU, 2019a). Of course, it is in their interest to seek new solutions to enhance their operational efficiency and to reduce their manufacturing costs. The EU Commission is engaging with key stakeholders operating in different value chains to identify the opportunities and challenges for the sustainable production and consumption of the following products:

\subsection{Batteries and vehicles}

The EU has introduced a batteries directive as from 2006. Since them it has been subject to a number of revisions. Its latest legislative proposal builds on the previous directive (EU, 2006) and on the work of the Batteries Alliance. In a nutshell, the EU's action plan is proposing specific rules and measures to improve the collection and recycling rates of all batteries (EU, 2020a, 2020b). It also emphasised the importance to phase out non-rechargeable batteries where alternatives exist. This EU document also referred to sustainability and transparency requirements for the production of batteries and has taken into account the carbon footprint from the sourcing 
of their raw materials through their production and consumption. The EU is pushing the automotive industry to comply with its stricter $\mathrm{CO} 2$ emission standards. It is encouraging the European vehicle owners to purchase Lithium-ion powered, electric vehicles (EV). The Commission has recognised that the use of lithium plays a strategic role in achieving zero-emission mobility, climate neutrality and technological leadership. At the same time, it contributes to enhance the sustainability of its economy.

Lithium is an important raw material for the production ofEV batteries, one of the six strategic value chains for the European economy. This metal is not featured in the EU's list of critical raw materials as it is not scarce. Its supply is not considered to be at risk. The EU has its own lithium reserves that are available for industrial-scale extraction. It very likely, that this soft, silvery-white alkali metal will be included in the EU's list of critical raw materials, as Europe will require higher volumes of lithium to mass-produce rechargeable batteries. Therefore, the EU together with the European battery manufacturing industry, is backing new initiatives to develop lithium mining and recycling activities as part of its concerted efforts to increase its production. In this light the EU has launched the European Battery Alliance in 2017. It brought together automakers, chemical and engineering executives in a bid to compete with Asian and American manufacturers. The EU wants to develop a strategic value chain for the manufacturing of electric car batteries within its territory.

However, the Europeans extant reliance on imported oil and gas should not be replaced by another dependency on lithium, cobalt, copper, and/or other raw materials that industries need for its green transition. One of the potential challenges is to recycle the used batteries after about 10 years. The used batteries can possibly play a much bigger role in secondary raw materials. Hence, the EU should ensure that there will be a business case for the stakeholders in the automotive 
industry to operate sustainably by recycling lithium from waste batteries in their manufacturing processes. Recently, COVID19 has led to a drop in the price of lithium, due to oversupply concerns. This issue may result in more usage of this white metal.

\subsection{Construction and buildings}

The Commission's European Green Deal had put forward its recommendations for energy efficiency in the EU in line with its circular economy principles, including the longer life expectancy of the buildings and reasonable recovery targets for construction and demolition waste, among other proposal. The EU's (2020) action plan is promoting the circularity principles to improve the durability and adaptability of buildings throughout their lifecycle. This document is addressing the safety and functionality of material recovery as it also makes reference to the sustainability performance of construction products. For example, it promotes initiatives to reduce soil sealing, to rehabilitate abandoned or contaminated brownfields and to increase the safe, sustainable and circular use of excavated soils.

One quarter of all waste that is generated in the EU comes from the construction and buildings industry (EU, 2019b). Such waste can be prevented by extending the lifetime of extant buildings, by reducing the living space per capita of new dwellings and by reusing building components for the same purpose for which they were conceived (Tam \& Lu, 2016). In practice, it may prove very difficult to reuse the building and construction materials like scrap metal, used cement or wood products, for the very same purpose for which they were conceived (Pomponi \& Moncaster, 2017; Smol, Kulczycka, Henclik, Gorazda \& Wzorek, 2015). For the time being, the used materials from demolition and renovation works are not suitable for reuse or for high-grade recycling (EEA, 2020). Therefore, the construction industry cannot achieve the EU's waste policy objectives, in terms of waste prevention. Currently, they are not in a position to use the recycled 
resources from the building sites, and/or to reduce the hazardous materials from construction waste (EEA, 2020; EU, 2019b).

Nevertheless, this sector is still considered a priority sector according to the latest European CE action plan (EU, 2020a; 2020b). In fact, the EU countries are scrutinising their waste management policies and practices. Several member states are recovering the construction waste for backfilling operations. Such waste and rubble are used to fill holes in construction sites. Alternatively, they may be using low-grade recovery waste such crushed cement or stones in road works. The cost to re-use construction material can be affected by the national and local circumstances; the mismatch of supply and demand; as well as by the logistical issues, like moving materials over long distances (Pomponi \& Moncaster, 2017; Smol et al., 2015). Moreover, such practices may also have an impact on the nearby communities and/or the natural environment. The construction and the development of the properties that use recycled materials may still require considerable scarce resources, in terms of time and money to complete them. Notwithstanding, the builders may be reluctant to re-use construction material that lacks an adequate certification of tested performance from a recognised authority.

The testing of the building materials can be expensive as it involves the thorough analyses of the samples to mitigate the risks of further use. These costs will be added to the material costs for the builders and may possibly override any savings from the reuse of extant material. Moreover, the latest construction techniques are increasingly combining traditional and novel building materials. This practice could impede the future builders to deconstruct and reuse the construction material. Notwithstanding, the reuse of some of the demolition waste, including furniture and equipment, may require requires selective demolition. In this case, the building contractor will have to sift through the construction waste to sort, clean and repair possible resources. Currently, 
there is an increase in demand for used construction and demolition materials. Such materials are usually given away free of charge or may be easily obtained through online marketplaces.

Better waste prevention as well as higher quality recycling can be achieved if certain measures are taken to improve the information on the construction materials that are being used in new buildings. This way, the building contractors would perceive the quality and value of the construction industry's secondary materials. Circular economy-inspired actions, like improved information sharing on material properties, and the optimal re-utilisation of secondary raw materials can go a long way in fostering the circular economy within the construction sector.

\subsection{Electronics and ICT}

Electrical and electronic equipment continues to be one of the fastest growing waste streams in the EU, with current annual growth rates of $2 \%$. It is estimated that less than $40 \%$ of this waste is recycled (EU, 2020a). About two out of three Europeans would like to keep using their technological devices for longer, if their performance is not significantly affected (Eurobarometer, 2020).

The waste of electrical and electronic equipment (WEEE) may include computers, printers, televisions, refrigerators, mobile phones, tablets and laptops. These electrical and electronic devices are the fastest growing waste streams within the EU. Their materials and components are made from scarce, hazardous resources. For example, the smartphones' components may include very precious and rare metals like gold, silver, copper, platinum and palladium, among others. The mining and extraction of these metals has an impact on the natural environmental at local, regional and global scales, as ecosystems are destroyed through waste spills and pollution (Liu, Li, Zuo, Zhang, \& Wang, 2009). As a result, there will be negative effects on the bio-diversity and on 
environmental sustainability. In this light, the EU's Directives on "waste electrical and electronic equipment" (WEEE) and on the "restriction of the use of hazardous substances" (RoHS) were intended to improve the collection, treatment and recycling of electronics at the end of their life. The electrical and electronic materials can cause major environmental and health problems if they are not collected, treated and/or recycled in an appropriate manner.

The first EU's WEEE Directive entered into force in February 2003 (WEEE, 2002). It provided information to the European citizens about how to dispose of their used electrical and electronic devices. In the same year, another EU legislation was enacted to restrict the use of hazardous substances in electrical and electronic equipment (RoHS 2002). This legislation restricted the use of hazardous substances including lead, mercury, cadmium, and hexavalent chromium and flame retardants such as polybrominated biphenyls (PBB) or polybrominated diphenyl ethers (PBDE) to safeguard the health and safety of individuals and protect the environment from heavy metals. Eventually, in 2012, the Commission revised this Directive that became effective on the 3rd January 2013 (RoHS, 2012). This revised legislation provided useful guideline for the creation of collection schemes where business, industry or consumers could return their hazardous substances free of charge.

In a similar vein, the EU has introduced another new WEEE directive to tackle the increased waste stream of EEEs (WEEE, 2012). This directive also stipulates that the EU member states are expected to collect and report data on the electrical and electronic products that are sold, collected, recycled and recovered. Various electrical and electronic materials may have different hazardous components in them. Therefore, the EU's WEEE (2012) directive specified that there are different targets for the recovery, reuse and recycling of different categories of electrical and electronic resources. A few EU countries are also disclosing other information on the reuse of 
whole appliances (on a voluntary basis). Currently, other devices like smart phones and tablets are being designed to be energy efficient, durable, repairable and/or upgradable, as their components can be reused or recycled (EU, 2020c; EU, 2019c). In addition, the upcoming Eco-design Working Plan will set out further regulatory measures on chargers for such devices, as it suggests the introducing a common charger for different devices, increasing the durability of charging cables, and providing incentives to decouple the purchase of chargers from the purchase of new devices (EU, 2019c).

\subsection{Food, water and packaging}

An estimated $20 \%$ of the total food produced is lost or wasted within the EU. Therefore, the food value chain and its generated waste is also increasing the pressure on the natural environment. In this light, EU (2008) has proposed a target to reduce food waste in its Farm-toFork Strategy (see EU, 2019a, 2019d). EU (2020a) has reaffirmed its commitment to increase the sustainability of food distribution and consumption. It indicated that it may amend its Drinking Water Directive (EU, 2019d) to make tap water drinkable and accessible in public places. This way, there will be less dependence on the bottled water and its packaging waste.

This document also raised awareness about its previous directive on reusable and recyclable packaging of materials and products (See EU, 1994). In 2017 the waste from packaging materials accounted to $173 \mathrm{~kg}$ per inhabitant. This figure is poised to increase year after year. It specified that a sustainable products initiative will include details on its proposed legislation to direct businesses and consumers to substitute single-use packaging, tableware and cutlery by reusable products in food services. The EU could restrict some packaging materials for certain applications, in particular where there are alternative, reusable products. These initiatives complement extant collection systems where there the packaging waste is separated at source. 
Currently, it is planning to establish specific rules for the safe recycling of food contact materials. The Commission may consider other systems where the consumer goods could be handled safely without packaging (EU, 2020a).

\subsection{Nutrients}

EU (2020a) announced that the Commission will develop an Integrated Nutrient Management Plan, with a view to ensuring that the member states will ensure the long-term sustainability of their nutrient resources and to stimulate the markets for recovered nutrients. For instance, this document refers to the new Water Reuse Regulation that encourages circular approaches to reuse water for agricultural purposes. The Commission also proposed that the secondary water could be reused by other industries (EU, 2019e). Currently, is assessing the possibility to use wastewater treatment and sewage sludge as a natural means of nutrient removal like algae.

Recently, the Farm Sustainability Tool (FaST) was developed to help farmers manage the use of nutrients in their farm. This tool (which is free of charge) was proposed in the framework of the Good Agricultural and Environmental Conditions (GAECs) and is part of the new common agricultural policy (CAP) proposals for 2021-27. In a nutshell, it aims to facilitate the sustainable use of fertilisers while boosting the use of the digital technologies in the agricultural sector. These latest CAP proposals are aimed to improve the competitiveness of the European farms, and to raise awareness about their environmental responsibility and on matters relating to the climate change. This tool can be accessed through a personal computer and via smart devices including smart phones and tablets. It provides useful data about the farms' resources, including crops, soil, the proximity of protected areas, the legal limits on the use of nutrients, animals, as well as the manure generated by them, among other issues. It may provide the farmers a nutrient management plan, 
including customised recommendations. For example, it includes information on; how to improve crop fertilisation, how to reduce nutrient leakages in ground water or rivers; how to increase soil quality and how to reduce greenhouse gas emissions. The tool will also make sense economically as it will help to decrease the use of nutrients and/or to increase crop yield. In both cases, this will lead to enhance the farmers' revenues and operational efficiencies. A few EU countries are already customising the functions and services of FaST to ensure that it is adapted to the local conditions, whilst taking advantage of the extant knowledge (EU, 2019e).

\subsection{Plastics}

The production of virgin plastic has increased 200-fold since 1950. It has grown at the rate of $4 \%$ a year since 2000 , even though it takes more than 400 years to degrade (WEF, 2019). To date, $12 \%$ of this plastic has been incinerated and just $9 \%$ has been recycled (Geyer, Jambeck \& Law, 2017; National Geographic, 2017). This material carries a carbon footprint when burned as waste. However, most plastics still exist in landfills or in our natural environments. Last year the EU passed ambitious new laws to reduce the consumption of single-use plastics. Currently, its research agenda is focused to investigate the risk and occurrence of microplastics in our food and drinking water. In this light, many European governments have imposed restrictions on the use of plastic bags. These measures were followed by considerable reductions of such waste in the citizens' litter. As a result, there was also less plastic in marine environments (Earthwatch Institute, 2019).

The European Parliament had emphasised that the prevention of plastic waste should be one of the Commission's first priorities (EP, 2018). Other European entities and stakeholders have pointed out that reducing the use of this material is required to improve our natural environment. Notwithstanding, the manufacture of these materials are increasing the demand for petrochemicals 
as they make up $99 \%$ of all plastics. For decades, oil and gas companies have created markets for their by-products or manage them as waste streams (OECD, 2019b; Wong, Ngadi, Abdullah \& Inuwa, 2015).

EU's (2020a) clarified that it is planning to introduce more stringent legislative instruments to eliminate the single-use food packaging, tableware and cutlery and replace them with reusable products by 2021. It has renewed its focus on tackling plastic pollution as it is expecting the manufacturers to reduce its use in foreseeable future. The commission recommended that they utilise biodegradable and recyclable packaging for their products. However, despite the EU (2019f) specified that the practitioners ought to reduce the consumption of the single-use plastic products and packaging, the industry is still producing and utilising plastic materials. At this stage, any efforts to reduce their leakage and/or to recycle them are inadequate and insufficient, as its consumption is still on the rise. The high rates of the consumption of plastics appear to be incompatible with addressing the environmental damage that is associated with their leakage (Wong et al., 2015). There are several stakeholders, including governments, intergovernmental organisations (EU, 2020; EU, 2019f; EASAC, 2020; UNEP 2018; 2020; OECD, 2019) and nongovernmental organisations in different contexts, that are increasingly calling for the reduction of plastic products. The industry practitioners are discouraged to continue the non-essential production as well as the unnecessary consumption of these materials.

\subsection{Textiles}

The production of textiles is highly globalised as there are billions of consumers that demand clothing, footwear and household products (Hu, Xiao, Zhou, Deng, Wang \& Ma, 2011). On average the Europeans consume about $26 \mathrm{~kg}$ of textiles per person, per year. In the EU, there are around 171000 companies that are providing employment to more than 1.7 million people 
within the textile and apparel industries. However, the EU is still a net importer of textiles and its exports comprise intermediate textile products, such as technical fibres and high-quality fabrics (EEA, 2019). Globally, the polyester is the most used fibre. It is produced from carbon-intensive processes requiring more than 70 million barrels of oil each year. The remaining fibres are mainly derived from cotton that necessitate vast stretches of land and water. The emerging economies are experiencing the major pressures to use their land to cultivate cotton.

From an EU consumption perspective, the clothing, footwear and household textiles are the fourth highest pressure category after food, housing and transport, as their production involves primary raw materials and water. Specifically, the textile industry is ranked as the second highest in terms of land use and it is fifth with regards to greenhouse gas emissions. It is estimated that the global manufacturing of textiles generates around 15-35 tonnes of $\mathrm{CO}_{2}$ per tonne of produced textiles. Within the EU, the production and handling of clothing, footwear and household textiles have generated emissions of $654 \mathrm{~kg} \mathrm{CO}_{2}$ per person (in 2017). Only $25 \%$ of this production and handling took place in Europe (see EEA, 2019). Moreover, the processes to produce textiles involve substantial amounts and a variety of chemicals. There are about 3,500 substances that are used in textile production. Of these, 750 have been classified as hazardous for human health and 440 as hazardous for the environment. It is estimated that about $20 \%$ of global water pollution is caused by dyeing and finishing textile products, affecting the health of workers and local communities (EEA, 2019). Furthermore, the washing of textiles also releases chemicals and microplastics into household wastewater.

Therefore, the production of textiles is impacting on our natural eco-systems and is putting considerable pressures on our climate (Hu et al., 2011). This is one of the industries that is affecting our climate in every phase of its production and consumption processes: from the manufacturing 
of fibres and textile products to distribution and retail, use of textiles, collection, sorting and recycling, and final waste management. Currently, the EU consumers are discarding about $11 \mathrm{~kg}$ of textiles per person, per year. A significant proportion of these material are exported to the developing countries, incinerated, or landfilled, as their recycling remains very low (EEA, 2019). It is estimated that less than $1 \%$ of all textiles worldwide are recycled into new textiles (EMF, 2017).

The European Commission has recognised that the textile industry as a priority area in one of its latest documents, entitled; "Towards an EU product policy framework contributing to the circular economy" (see EU, 2015b). Furthermore, the new European Commission President Ursula von der Leyen has also pledged her commitment to implement the new circular economy action plan. In her own words, she specified that she would focus on "sustainable resource use, especially in resource intensive and high-impact sectors such as textiles and construction" (EUWID, 2019). In fact, this year, the Commission is proposing a comprehensive EU Strategy for Textiles (EU, 2020a). The aim of this strategy is to bolster the competitiveness and sustainability innovation in the textiles sector. In sum, the EU's (2020a) document specified that this can be achieved by employing its new sustainable product framework. This framework suggests that the manufacturers of textile materials ought to follow eco-designs and sustainability measures to ensure that they are engaging in closed loop systems. Such systems would require that they use and reuse secondary raw materials, tackle the presence of hazardous chemicals, empower the businesses and their consumers to choose sustainable textiles and have easy access to re-use and repair services (EU, 2020a).

Moreover, the EU and the respective governments of its member states needs to provide incentives and support to facilitate closed loop and product- service systems, by raising awareness 
on such sustainable production and consumption processes, by increasing their engagement with different marketplace stakeholders in the value chain, and by enabling industry practitioners to access and to avail themselves of secondary resources (EU, 2020a; Camilleri, 2018).

\section{Discussion}

In the past decade, the EU Commission and its agencies have been instrumental in raising more awareness on sustainable innovation and on circular economic models. This contribution suggests that there is scope for the EU and the respective governments of its member states to forge relationships with marketplace stakeholders, including suppliers and distributors in order to implement the circular economy. Currently, the public regulatory authorities as well as the industry practitioners are increasingly seeing the potential economic, social, environmental and climate benefits of engaging in the circular economy's closed loop and product service systems (Camilleri, 2018; Lieder \& Rashid, 2016; Ghisellini et al., 2015; Tukker, 2015; Tukker \& Tischner, 2006). Many manufacturers are already perceiving the business case for the circular economy as they are using and reusing secondary resources. There are various businesses and non profit organisations that are engaged in repairing, refurbishing, restoring and/or recycling materials.

On the other hand, there are other practitioners that are opting to remain in their status quo as they rely on traditional, linear economic models (Bocken, de Pauw et al., 2016). This chapter referred to some other challenges that could slow down or prevent the businesses' engagement in the circular economy's sustainable approaches. It presented a cost- benefit analysis of advancing the circular economy strategy. Afterwards, it featured a critical review of the latest European Circular Economy Action Plan that comprises a sustainable product policy framework (EU, 2020a, 
2020b). This research evaluated the Commission future-oriented agenda that is intended to foster a cleaner and more competitive Europe.

In sum, it shed light on the value chains of different products and resources, including batteries and vehicles, electronics/electrical products and components, packaging, food, water and nutrients, textiles, construction and building materials and plastics, among others. Arguably, it may appear that this plan has paved the way for more interrelated circular economy initiatives in different industry sectors. The EU is encouraging the businesses as well as their consumers to engage in sustainable production and consumption behaviours and to use and reuse products, materials and resources. This way they will minimise their impact on the natural environment, in terms of the generation of waste and emissions. Indeed, the EU's latest policy proposals as well as its action plans are a step in the right direction as they include key recommendations on our way forward towards a regenerative circular economy model.

\section{Key Recommendations}

The transition to the circular economy ought to be systemic, deep and transformative, within the EU context and beyond. It is very likely that it will be disruptive as it requires cooperation of all stakeholders including the policy makers, industry practitioners, consumers and non-government organisations, among others. The transition towards the circular economy can be facilitated if the governments would create a favourable climate for responsible, positive impact investing, by providing technical assistance and mobilising financial resources for sound investments in sustainable innovations (Camilleri, 2020; 2015b). For instance, the European Green Deal Investment Plan (EIP) is currently supporting the sectors relating to the provision of sustainable energy, energy efficiency, sustainable cities and sustainable agricultural practices, among other areas. 
The transition towards the circular economy is dependent on the stakeholders' willingness and capacity to collaborate and forge long term relationships with one another. There are many lessons to be learned from good practice as well as on failures. Success stories point out on the need to promote the economic return on investment, process improvements and product benefits to motivate businesses and investors to shift from the linear economy to the circular economy. The case studies of the responsible businesses that resorted to closed loop systems are indicating that there is market for used materials and resources. Moreover, many countries are providing the appropriate conditions for the development of clusters at supply chain level, as they enable businesses to exchange waste resources (EU, 2015; Geng, Zhang, Côté \& Fujita, 2009). Any reductions in waste could translate to lower costs for the businesses themselves, as they do not need to handle, transport and store waste prior to its disposal. As a result, businesses will consume lower energy in their production processes.

The main challenge is to create the right environment where businesses collaborate in supply chains. The development of clusters and eco-industrial parks would help them to turn their unwanted externalities into useable materials for others. Some industries lend themselves to circular initiatives more than others as the recirculation of their resources may be straightforward. For example, primary industries such as iron, steel and aluminium may need to be incentivised to minimise their waste in closed loop systems. Other industries, including solar and wind energy technologies, battery production and biotech materials will inevitably have to be re-assessed on the basis of their recirculation potential and performance over their whole life cycles.

The circular economy concept has the potential to maximise the functioning of global ecosystems Camilleri, 2018a; Kirchherr et al., 2017; Murray et al., 2017; Liu et al., 2019; Stubbs \& Cocklin, 2008). Everyone has a responsibility to bear for the products' disposal at their end of 
the life. The businesses are encouraged to measure their direct and indirect environmental impacts. Circular-economy measures and eco labels may have to be developed for the big businesses and large undertakings. At present, there is no way of measuring how the companies are effectively circulating materials and resources in their manufacturing processes.

The circular economy metrics can assess the ecological footprint of the businesses' sustainable production and consumption of materials and products during their operational processes. These metrics may also measure the economic benefits that can accrue from the adoption of closed loop systems. There is also scope for many corporations to legitimate and consolidate their social licence to operate. They are expected to comply (if they are still not complying) with the EU's non-financial reporting directive (Venturelli et al., 2019; Camilleri, 2015) and provide adequate and sufficient information on how they are transiting towards the circular economy strategy in their corporate disclosures (Camilleri, 2017b; 2018b).

\section{Acknowledgements}

The author thanks the editors and reviewers for their kind support.

\section{References}

Bocken, N. M., de Pauw, I., Bakker, C. \& van der Grinten, B. (2016). Product design and business model strategies for a circular economy. Journal of Industrial and Production Engineering, 33(5), 308-320.

Camilleri, M. A. (2015a). Environmental, social and governance disclosures in Europe. Sustainability Accounting, Management and Policy Journal, 6(2), 224-242.

Camilleri, M. A. (2015b). Valuing stakeholder engagement and sustainability reporting. Corporate Reputation Review, 18(3), 210-222. 
Camilleri, M. A. (2017a). Case Study 5: Closing the Loop of the Circular Economy for Corporate Sustainability and Responsibility. In Corporate Sustainability, Social Responsibility and Environmental Management (pp. 175-190). Springer, Cham.

Camilleri, M. A. (2017b). The integrated reporting of financial, social and sustainability capitals: a critical review and appraisal. International Journal of Sustainable Society, 9(4), 311-326.

Camilleri, M.A. (2018a). The Circular Economy's Closed Loop and Product Service Systems for Sustainable Development: A Review and Appraisal. Sustainable Development. 27(3), 530-536.

Camilleri, M.A. (2018b). Theoretical Insights on Integrated Reporting: The Inclusion of NonFinancial Capitals in Corporate Disclosures. Corporate Communications: An International Journal. 23(4), 567-581.

Camilleri, M.A. (2020). The market for socially responsible investing: A review of the developments. Social Responsibility Journal. Forthcoming. 10.1108/SRJ-06-2019-0194

Earthwatch (2019). Plastic Rivers: Tackling the pollution on our doorsteps https://earthwatch.org.uk/get-involved/plastic-rivers (Accessed 13 ${ }^{\text {th }}$ April, 2020).

EASAC (2020). Packaging plastics in the circular. European Academies Science Advisory Council, Halle Germany. https://easac.eu/fileadmin/PDF_s/reports_statements/Plastics/EASAC_Plastics_complete_Web_ PDF.pdf (Accessed 13 ${ }^{\text {th }}$ April 2020).

EEA (2018). Waste prevention in Europe — policies, status and trends in reuse in 2017. European Environment Agency, Luxembourg.

EES (2019). Textiles in Europe's circular economy. https://www.eea.europa.eu/themes/waste/resource-efficiency/textiles-in-europe-s-circulareconomy (Accessed $13^{\text {th }}$ April 2020).

EEA (2020). Improving circular economy practices in the construction sector key to increasing material reuse, high quality recycling. https://www.eea.europa.eu/highlights/improving-circulareconomy-practices-in (Accessed $13^{\text {th }}$ April 2020).

EP (2018). A European Strategy for Plastics in a circular economy. https://www.europarl.europa.eu/doceo/document/TA-8-2018-0352_EN.html (Accessed 13 ${ }^{\text {th }}$ April 2020).

EMF (2013). Towards the Circular Economy, Ellen MacArthur Foundation Rethinking the Future. http://www.ellenmacarthurfoundation.org/assets/downloads/publications/TCE_Report2013.pdf (Accessed 13 ${ }^{\text {th }}$ April 2020). 
EMF (2017). A New Textiles Economy: Redesigning Fashion's Future.

https://www.ellenmacarthurfoundation.org/publications/a-new-textiles-economy-redesigningfashions-future (Accessed 13 ${ }^{\text {th }}$ April 2020).

EU (1994). European Parliament and Council Directive 94/62/EC of 20 December 1994 on packaging and packaging waste, OJ L 365 31.12.1994, p. 10. https://eur-lex.europa.eu/legalcontent/en/TXT/?uri=CELEX:31994L0062 (Accessed 13 ${ }^{\text {th }}$ April 2020).

EU (2006). Directive 2006/66/EC of the European Parliament and of the Council of 6 September 2006 on batteries and accumulators and waste batteries and accumulators and repealing Directive 91/157/EEC, OJ L 266, 26.9.2006, p. 1. (Accessed $13^{\text {th }}$ April 2020).

EU (2008). Directive 2008/98/EC of the European Parliament and of the Council of 19

November 2008 on waste and repealing certain Directives (Text with EEA relevance) https://eur-lex.europa.eu/legal-content/EN/TXT/?uri=celex\%3A32008L0098 $\left(\right.$ Accessed $13^{\text {th }}$ April, 2020).

EU (2014). Non-financial reporting. European Commission, Brussel, Belgium.

http://ec.europa.eu/internal_market/ accounting/non-financial_reporting/index_en.htm (accessed $13^{\text {th }}$ April 2020).

EU (2015a). Closing the loop - An EU action plan for the Circular Economy, Communication from the Commission to the European Parliament, the Council, The European Economic and Social Committee and the Committee of the Regions. http://eur-lex.europa.eu/legalcontent/ EN/TXT/HTML/?uri=CELEX:52015DC0614andfrom=EN (Accessed 13 ${ }^{\text {th }}$ April 2020).

EU (2015b). Towards an EU product policy framework contributing to the circular economy. https://ec.europa.eu/info/law/better-regulation/have-your-say/initiatives/1740-Towards-an-EUProduct-Policy-Framework-contributing-to-the-Circular-Economy (Accessed 13 ${ }^{\text {th }}$ April, 2020).

EU (2017). Council conclusions on eco-innovation: enabling the transition towards a circular Economy. European Council of the European Union.

http://www.consilium.europa.eu/en/press/press-releases/2017/12/18/council-conclusions-onecoinnovation-transition-towards-a-circular-economy/\# (Accessed $13^{\text {th }}$ April 2020).

EU (2019a). Farm to Fork strategy for sustainable food. https://ec.europa.eu/food/farm2fork_en (Accessed 13 ${ }^{\text {th }}$ April, 2020).

EU (2019b). Construction and demolition waste. European Commission, Brussel, Belgium. https://ec.europa.eu/environment/waste/construction_demolition.htm (accessed 5th March 2020)

EU (2019c). Preparatory study for the Ecodesign Working Plan 2020-2024.

https://ec.europa.eu/growth/content/preparatory-study-ecodesign-working-plan-2020-2024 en (Accessed 31st March 2020). 
EU (2019d). The drinking water directive. https://ec.europa.eu/environment/water/waterdrink/legislation_en.html (Accessed 31st March 2020).

EU (2019e). A new tool to increase the sustainable use of nutrients across the EU.

https://ec.europa.eu/info/news/new-tool-increase-sustainable-use-nutrients-across-eu-2019-feb19_en (Accessed 31st March 2020).

EU (2019f). EU Directive 2019/904 Of the European Parliament and of the Council of 5 June 2019 on the reduction of the impact of certain plastic products on the environment. https://eurlex.europa.eu/legal-content/EN/TXT/PDF/?uri=CELEX:32019L0904 (Accessed $13^{\text {th }}$ April, 2020).

EU (2020a). Commission Staff Working Document. Leading the way to a global circular economy: state of play and outlook. European Commission, Brussel, Belgium.

https://ec.europa.eu/environment/circulareconomy/pdf/leading_way_global_circular_economy.pdf (Accessed 31st March 2020).

EU (2020b). A new circular economy plan for a cleaner and more competitive Europe. European Commission, Brussels, Belgium. https://eur-lex.europa.eu/legal-

content/EN/TXT/?qid=1583933814386\&uri=COM:2020:98:FIN (Accessed 13 ${ }^{\text {th }}$ April 2020).

EU (2020c). Guidance for the Assessment of Material Efficiency: Application to Smartphones. JRC Technical Report. Luxembourg.

https://publications.jrc.ec.europa.eu/repository/bitstream/JRC116106/jrc116106_jrc_e4c_task2_s martphones_final_publ_id.pdf (Accessed 13 ${ }^{\text {th }}$ April, 2020).

Eurobarometer (2020). Special Eurobarometer 503: Attitudes towards the impact of digitalisation on daily lives. EU Open Data Portal.

https://data.europa.eu/euodp/en/data/dataset/S2228 $92 \quad 4 \quad 503$ ENG (Accessed $13^{\text {th }}$ April 2020).

EUWID (2019). New European Action Plan for the Circular Economy. EUWID Recycling and Waste Management. https://www.euwid-recycling.com/news/policy/single/Artikel/neweuropean-action-plan-for-the-circular-economy.html (Accessed $13^{\text {th }}$ April 2020).

Geng, Y. \& Doberstein, B. (2008). Developing the circular economy in China: Challenges and opportunities for achieving leapfrog development. The International Journal of Sustainable Development and World Ecology. 15(3), 231-239.

Geng, Y., Zhang, P., Côté, R. P. \& Fujita, T. (2009). Assessment of the National Eco-Industrial Park Standard for Promoting Industrial Symbiosis in China. Journal of Industrial Ecology, 13(1), 15-26.

Geng, Y., Sarkis, J., Ulgiati, S. \& Zhang, P. (2013). Measuring China's circular economy', Science, 339 (6127), 1526-1527.

Geissdoerfer, M., Savaget, P., Bocken, N. M. \& Hultink, E. J. (2017). The Circular Economy- 
A new sustainability paradigm? Journal of Cleaner Production, 143, 757-768.

Geyer, R., Jambeck, J. R., \& Law, K. L. (2017). Production, use, and fate of all plastics ever made. Science advances, 3(7), 1-5.

Ghisellini, P., Cialani, C., \& Ulgiati, S. (2016). A review on circular economy: the expected transition to a balanced interplay of environmental and economic systems. Journal of Cleaner Production, 114, 11-32.

Haas, W., Krausmann, F., Wiedenhofer, D., \& Heinz, M. (2015). How circular is the global economy? An assessment of material flows, waste production, and recycling in the European Union and the world in 2005. Journal of Industrial Ecology, 19(5), 765-777.

Kirchherr, J., Reike, D., \& Hekkert, M. (2017). Conceptualizing the circular economy: An analysis of 114 definitions. Resources, Conservation and Recycling, 127, 221-232.

Hu, J., Xiao, Z., Zhou, R., Deng, W., Wang, M. and Ma, S. (2011). Ecological utilization of leather tannery waste with circular economy model, Journal of Cleaner Production, 19(2), 221228.

Lieder, M. \& Rashid, A. (2016). Towards circular economy implementation: a comprehensive review in context of manufacturing industry. Journal of Cleaner Production, 115, 36-

51.

Mont, O. K. (2002). Clarifying the concept of product-service system, Journal of Cleaner Production, 10(3), 237-245.

Moratis, L., Melissen, F., \& Idowu, S. O. (2018). Sustainable Business Models. Springer, Cham.

Murray, A., Skene, K., and Haynes, K. (2017). The circular economy: An interdisciplinary exploration of the concept and application in a global context. Journal of Business Ethics, 140(3), 369-380.

National Geoographic (2018). A whopping 91\% of plastic isn't recycled. https://www.nationalgeographic.com/news/2017/07/plastic-produced-recycling-waste-oceantrash-debris-environment/ (Accessed $13^{\text {th }}$ April 2020).

OECD (2019a). Global Material Resources Outlook to 2060.

https://www.oecd.org/environment/global-material-resources-outlook-to-2060-9789264307452en.htm (Accessed 13 ${ }^{\text {th }}$ April 2020).

OECD (2019b). Policy approaches to incentivize sustainable plastic design. Environment Working Paper No. 149.

https://www.oecd.org/officialdocuments/publicdisplaydocumentpdf/?cote=ENV/WKP(2019)8\& docLanguage $=$ En $\left(\right.$ Accessed $13^{\text {th }}$ April 2020). 
Peeters, J. R., Vanegas, P., Tange, L., Van Houwelingen, J., \& Duflou, J. R. (2014). Closed loop recycling of plastics containing Flame Retardants, Resources, Conservation and Recycling, 84, 35-43.

Pomponi, F., \& Moncaster, A. (2017). Circular economy for the built environment: A research framework. Journal of Cleaner Production, 143, 710-718.

Porter, M. E. \& Van der Linde, C. (1995). Green and competitive: ending the stalemate, Harvard Business Review, 73(5), 120-134.

Prakash, A. (2002). Green marketing, public policy and managerial strategies. Business Strategy and the Environment, 11(5), 285-297.

RoHS (2002). Directive 2002/95/EC of the European Parliament and of the Council of 27 January 2003 on the restriction of the use of certain hazardous substances in electrical and electronic equipment. https://eur-lex.europa.eu/legalcontent/EN/TXT/HTML/?uri=CELEX:32002L0095\&from=EN (Accessed 15 ${ }^{\text {th }}$ March 2020).

Smol, M., Kulczycka, J., Henclik, A., Gorazda, K., \& Wzorek, Z. (2015). The possible use of sewage sludge ash (SSA) in the construction industry as a way towards a circular economy. Journal of Cleaner Production, 95, 45-54.

Stahel, W. R. (2016). Circular economy: a new relationship with our goods and materials would save resources and energy and create local jobs, Nature, 531(7595), 435-439.

Stubbs, W., and Cocklin, C. (2008). Conceptualizing a sustainability business model. Organization and Environment, 21(2), 103-127.

Tam, V. W. Y., \& Lu, W. (2016). Construction waste management profiles, practices, and performance: a cross-jurisdictional analysis in four countries. Sustainability, 8(2), 190-206.

Tukker, A. \& Tischner, U. (2006). Product-services as a research field: past, present and future. Reflections from a decade of research. Journal of Cleaner Production, 14(17) 1552-1556.

Tukker, A. (2015). Product services for a resource-efficient and circular economy-a review', Journal of Cleaner Production, 97, 76-91.

UNEP (2018). Single Use Plastic.

https://wedocs.unep.org/bitstream/handle/20.500.11822/25496/singleUsePlastic_sustainability.p df(Accessed 13 ${ }^{\text {th }}$ April 2020).

UNEP (2019). Global Resources Outlook. Natural Resources for the future we want. https://www.resourcepanel.org/file/1191/download?token=oxkXHwCD (Accessed $13^{\text {th }}$ April 2020). 
UNEP (2020). Stocktaking of initiative on plastic waste.

http://www.basel.int/Implementation/Plasticwaste/PlasticWastePartnership/Meetings/PWPWG1/ tabid/8305/ctl/Download/mid/23074/Default.aspx?id=9\&ObjID=22867 (Accessed $13^{\text {th }}$ April 2020).

Venturelli, A., Caputo, F., Leopizzi, R., \& Pizzi, S. (2019). The state of art of corporate social disclosure before the introduction of non-financial reporting directive: A cross country analysis. Social Responsibility Journal.15 (4), 409-423.

Wang, G.H., Wang, Y.N., Zhao, T. (2008). Analysis of interactions among barriers to energy saving in China'. Energy Policy. 36, 1879- 1889.

WEEE (2002). Directive 2002/96/EC of the European Parliament and of the Council of 27 January 2003 on waste electrical and electronic equipment (WEEE) - Joint declaration of the European Parliament, the Council and the Commission relating to Article 9 https://eurlex.europa.eu/legal-content/EN/TXT/?uri=CELEX:32002L0096 (Accessed 13 ${ }^{\text {th }}$ April 2020).

WEEE (2012). Directive 2012/19/EU of the European Parliament and of the Council $f 4$ July 2012 on waste electrical and electronic equipment (WEEE) https://eur-lex.europa.eu/legalcontent/EN/TXT/?uri=CELEX:32012L0019 $\left(\right.$ Accessed 13 ${ }^{\text {th }}$ April 2020).

WEF (2019). 5 steps that could end the plastic pollution crisis - and save our ocean https://www.weforum.org/agenda/2019/03/5-steps-that-could-end-the-plastic-pollution-crisisand-save-our-oceans-eb7d4caf24/ (Accessed $13^{\text {th }}$ April 2020).

Wong, S. L., Ngadi, N., Abdullah, T. A. T., \& Inuwa, I. M. (2015). Current state and future prospects of plastic waste as source of fuel: A review. Renewable and sustainable energy reviews, 50, 1167-1180.

World Bank (2018). What a Waste 2.0: A Global Snapshot of Solid Waste Management to 2050. https://www.worldbank.org/en/news/infographic/2018/09/20/what-a-waste-20-a-globalsnapshot-of-solid-waste-management-to-2050 (Accessed $13^{\text {th }}$ April 2020). 